\title{
DNA polymerase activity in rheumatoid synovial membranes
}

\author{
MARY NORVAL, MARIE M. OGILVIE, AND B. P. MARMION \\ From the Department of Bacteriology, Edinburgh University Medical School, Teviot Place, \\ Edinburgh EH8 $9 A G$
}

\begin{abstract}
Norval, M., Ogilvie, M. M., and Marmion, B. P. (1975). Annals of the Rheumatic Diseases, 34, 205-212. DNA polymerase activity in rheumatoid synovial membranes. RNase-sensitive DNA polymerase activity was demonstrated in synovial membrane preparations from 23 out of 25 rheumatoid arthritis patients. Control groups consisted of twelve patients with osteoarthrosis, four with secondary osteoarthrosis, and twelve with other conditions. The last group showed no activity, while the results with the other two groups were varied. The properties of the polymerase enzyme, such as its stimulation by synthetic templates and inhibition by actinomycin $\mathrm{D}$, were not consistent with it being associated with an oncogenic virus; it seems to be more like that found in stimulated normal human lymphocytes, described as an RNA-primed DNA-directed DNA polymerase.
\end{abstract}

The view that an infective agent provides the initiating stimulus for the complex immunological and inflammatory process in the rheumatoid joint is attractive, but little or no definitive evidence has yet been produced to implicate either procaryotes or viruses. Several workers have failed to find either a cytopathic virus in synovial cells or evidence of a substantial, productive, noncytopathic virus infection (reviewed by Marmion, 1975). The remaining possibilities for persistent viral infection of the synovium include a defective, nonproductive, cytoplasmic infection, probably with an RNA virus, accompanied by formation of viral gene products that give a new antigenicity to the host cell. Alternatively, there might be integration of viral DNA into the host cell genome, again with expression of some genes giving rise to host cell modification. Such an integrated viral genome might originate directly from a DNA virus or be copied from an RNA template belonging to an oncorna or leucovirus by virus-coded RNA-dependent DNA polymerase (reverse transcriptase) (Baltimore, 1970; Temin and Mizutani, 1970).

Reverse transcriptase can be measured by the incorporation of ${ }^{3} \mathrm{H}$-thymidine triphosphate into an acid-insoluble product that can be shown to be an RNA-DNA hybrid sensitive to DNase. The template for the enzyme has a characteristic buoyant density and is sensitive to RNase. The DNA product of the reaction can be extracted and analysed by equilibrium density centrifugation. It is complementary to the template RNA extracted from purified virions, if these are available (Sarngadharan, Sarin, Reitz, and Gallo, 1972).

Accepted for publication October 24, 1974.
These discoveries have opened up new possibilities for the detection of oncorna virus genes in cells. Apart from this approach, general methods of demonstrating an oncorna virus include the visualization of C-type particles in thin sections of cells or tissues in the electron microscope, showing interspecies gs antigen in cells or virions, and the growth of virus or rescue of genetic markers in cell culture.

The present unavailability of an accepted human oncorna virus and lack of knowledge of the cell types that would support its multiplication restrict the different lines of investigation needed to detect and validate oncorna viruses as possible aetiological agents in rheumatoid arthritis (RA). However, morphological studies, examination for gs antigen, and assay for reverse transcriptase might be used to obtain at least preliminary indications of viral activity. Various mammalian cell lines and human neoplasias have recently been investigated in this way (Spiegelman, Kufe, Hehlmann, and Peters, 1973).

Schumacher (1973) and Neumark, Hollos, and Farkas (1973) have reported the presence of C-type particles in thin sections of synovial membrane cells of patients with RA. Palmer and Myers (1973) attempted to show reverse transcriptase activity in a rheumatoid cell line with a questionable result due to the probable presence of a nuclease. However. Spruance, Richards, Ward, and Smith (1974) showed reverse transcriptase activity in cultured rheumatoid synovial cell strains and also found it in normal synovial cell strains.

In general, the demonstration of enzyme activity resembling that of a reverse transcriptase, unsupported by other evidence, cannot be taken as definitive 
Table I Clinical and laboratory details of patients with arthritis

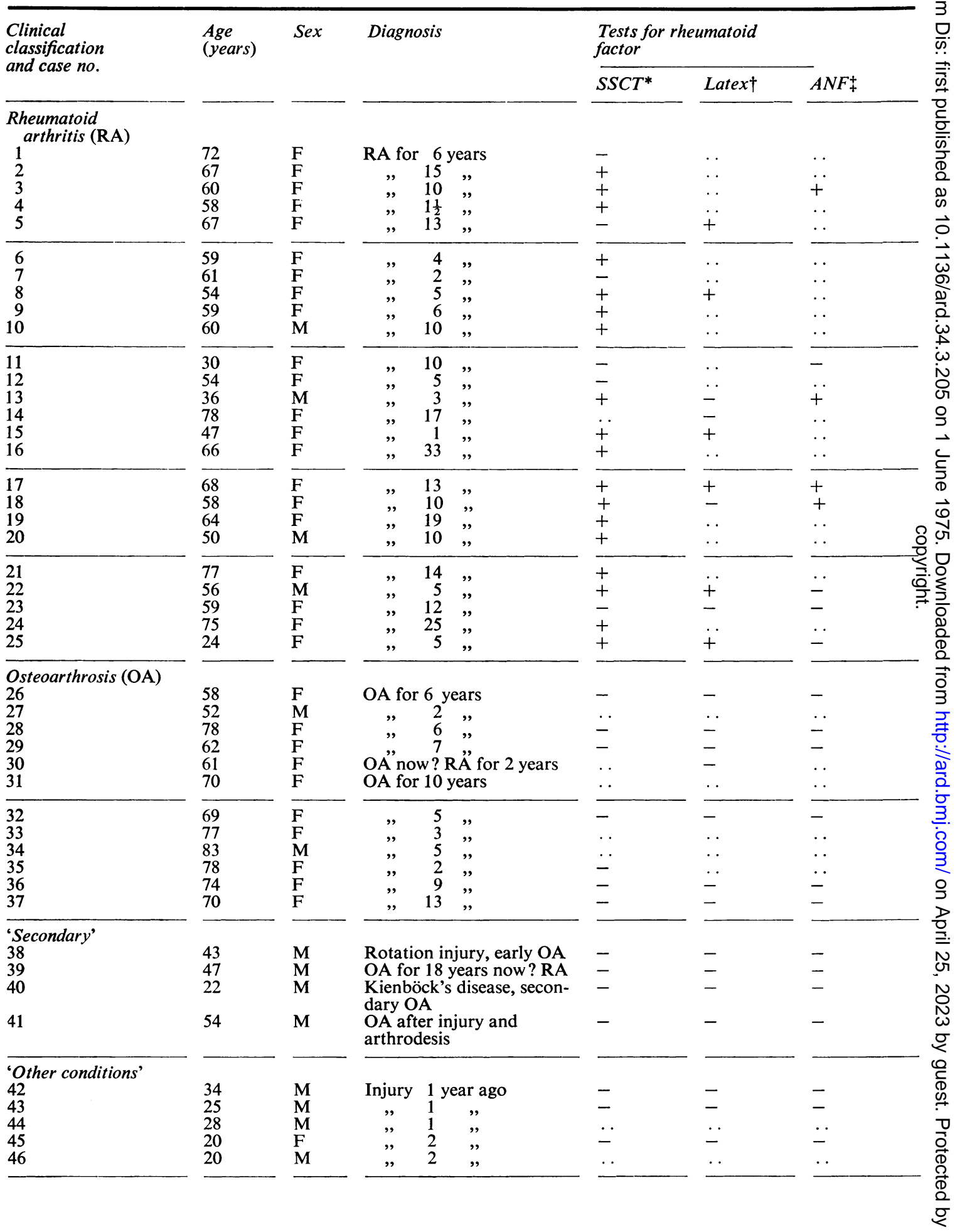


Table I (continued)

\begin{tabular}{|c|c|c|c|c|c|c|c|}
\hline \multirow{2}{*}{$\begin{array}{l}\text { Clinical } \\
\text { classification } \\
\text { and case no. }\end{array}$} & \multirow[t]{2}{*}{$\begin{array}{l}\text { Age } \\
\text { (years) }\end{array}$} & \multirow[t]{2}{*}{$\operatorname{Sex}$} & \multirow{2}{*}{\multicolumn{2}{|c|}{ Diagnosis }} & \multicolumn{2}{|c|}{$\begin{array}{l}\text { Tests for rheumatoid } \\
\text { factor }\end{array}$} & \multirow[b]{2}{*}{$A N F \ddagger$} \\
\hline & & & & & $S S C T^{*}$ & Latex $\dagger$ & \\
\hline $\begin{array}{l}47 \\
48 \\
49 \\
50 \\
51 \\
52 \\
53\end{array}$ & $\begin{array}{l}20 \\
33 \\
28 \\
38 \\
29 \\
47 \\
57\end{array}$ & $\begin{array}{l}\mathbf{M} \\
\mathbf{M} \\
\mathbf{M} \\
\mathbf{M} \\
\mathbf{M} \\
\mathbf{M} \\
\mathbf{M}\end{array}$ & 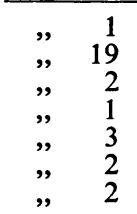 & $\begin{array}{l}\text { ", } \\
\text { ”, } \\
\text { ”, }\end{array}$ & $\begin{array}{l}\overline{-} \\
\overline{.} \\
\ddot{-} \\
\overline{-} \\
.\end{array}$ & $\begin{array}{l}\overline{-} \\
- \\
\ddot{-} \\
\overline{-} \\
.\end{array}$ & $\begin{array}{l} \\
- \\
\cdots \\
- \\
- \\
\ldots\end{array}$ \\
\hline
\end{tabular}

* SSCT (sensitized sheep cell test) = agglutination of sheep red cells coated with specific rabbit antibody.

$\dagger$ Latex test $=$ agglutination of latex particles coated with IgG globulin.

$\mp \mathrm{ANF}=$ antinuclear factor.

+ Indicates a titre of $\geqslant 128$ on one or more occasions.

.. Indicates that the serum was not available.

evidence of oncorna virus activity. Cell polymerases will synthesize DNA on some synthetic RNA or mixed RNA/DNA templates giving rise to erroneous conclusions. In addition, another DNA polymerase, primed by RNA, has been shown in stimulated, normal human lymphocytes; this can be distinguished from viral reverse transcriptase in several of its properties-in particular its inability to transcribe the heteropolymeric regions of 70S RNA tumour viruses (Bobrow, Smith, Reitz, and Gallo, 1972).

An investigation of the nucleic acid polymerase activity of synovial membranes from patients with RA, degenerative arthritis, and other conditions has been undertaken to explore these problems and potential artefacts in a search for oncorna virus in RA.

\section{Materials and methods}

\section{CLINICAL POPULATION (TABLE I)}

The synovial membranes from 25 RA patients undergoing synovectomy were used. Controls comprised membranes from 3 groups of patients. The first group of twelve had osteoarthrosis and the second group of four had secondary osteoarthritis. The remaining group, 'other conditions', contained twelve patients requiring arthrotomy after injury, 11 of these having torn menisci.

\section{ENZYME EXTRACTS}

Within 2 hours of operation the synovial lining membranes were dissected from the bulk of surrounding fibrous and fatty tissue and cut into very small pieces. The wet weight of the tissue varied from $0 \cdot 2-5 \mathrm{~g}$, and it was homogenized by hand or with a Potter-Elvehjem homogenizer in a small volume of $0.01 \mathrm{~mol} / 1 \mathrm{Tris}-\mathrm{HCl}$ buffer $\mathrm{pH} 8.0$, containing $0.001 \mathrm{~mol} / 1$ EDTA and $0.25 \mathrm{~mol} / 1$ sucrose. These extracts were frozen and stored at $-70^{\circ} \mathrm{C}$. The cells were disrupted with Nonidet P-40 according to the method of Coffin and Temin (1971), and the high-speed pellet suspended in a small volume of buffer used in the polymerase assay. Pro- tein content was estimated by the method of Lowry' Rosebrough, Farr, and Randall (1951). The extracts were stored in small aliquots at $-70^{\circ} \mathrm{C}$ and were normally used only once and not refrozen.

\section{POLYMERASE ASSAYS}

Assays were performed by the method of Temin and Mizutani (1970) using 0.125 $\mu \mathrm{mol}$ dGTP, $0.125 \mu \mathrm{mol}$ dATP, $0 \cdot 125 \mu \mathrm{mol}$ dCTP, $2 \cdot 5 \mu \mathrm{mol}$ phospho(enol)pyruvate, $10 \mu \mathrm{g}$ pyruvate kinase ( $320 \mathrm{units} / \mathrm{mg}$ ), $2 \mu \mathrm{mol}$ dithiothreitol (all from Sigma), $0 \cdot 8 \%$ Nonidet P-40, $1 \cdot 25 \mu \mathrm{mol} \mathrm{MgCl}, 2 \cdot 5$ $\mu \mathrm{mol} \mathrm{KCl}, 2.5 \mu \mathrm{Ci}{ }^{3} \mathrm{H}$-methyl-TTP $(25 \mathrm{Ci} / \mu \mathrm{mol}$, Amersham), 10, 20, or $40 \mu$ l enzyme preparation, and buffer $(0.02 \mathrm{~mol} / 1 \mathrm{Tris}-\mathrm{HCl} \mathrm{pH} 8.0$ containing $0.33 \mathrm{mmol} / 1$ EDTA and $1.7 \mathrm{mmol} / 12$-mercaptoethanol) to make a total volume of $140 \mu \mathrm{l}$. Incubation was carried out at $37^{\circ} \mathrm{C}$ for a period of between 45 and $120 \mathrm{~min}$. Samples of $30 \mu \mathrm{l}$ were spotted on filter paper discs at intervals of 15,20 , or 30 min. Filters were fixed in cold $10 \%$ trichloroacetic acid (TCA), washed 5 times in cold $10 \%$ TCA and then in cold ethanol before being air dried and counted in PPOtoluene scintillator in a Packard Tri-Carb liquid scintillation instrument.

For information on the nature of the primer or template, some samples were pretreated with $10 \mu$ g pancreatic ribonuclease (100 units $/ \mathrm{mg}$, Sigma) at $0^{\circ} \mathrm{C}$ for $10 \mathrm{~min}$ before adding the assay constituents. Ribonuclease had previously been heated at $70^{\circ} \mathrm{C}$ for $10 \mathrm{~min}$ to destroy any deoxyribonuclease activity.

The artificial templates/primers poly-deoxy-adenylicdeoxy-thymidylic acid (poly-d(A-T)) and polyadenylic acid decathymidylic acid (poly-A. dT $_{10}$ ) were used at concentrations of $0.07 \mathrm{OD}_{260}$ units/ml (Boehringer Corp.).

The effect of actinomycin $D$ was found by the addition of $50 \mu \mathrm{g} / \mathrm{ml}$ (Sigma) dissolved in polymerase buffer at the start of the reaction.

\section{PRODUCT ANALYSIS}

Standard reaction mixtures as outlined above were scaled up to $0.6 \mathrm{ml}$ and were incubated at $37^{\circ} \mathrm{C}$ for $20 \mathrm{~min}$. The products were extracted with phenol-cresol and analysed on $\mathrm{Cs}_{2} \mathrm{SO}_{4}$ density gradients (Sarngadharan and others, 
Table II Polymerase activity of synovial membrane cells, expressed as increase in cpm incorporated into acid insoluble material in $30 \mathrm{~min} / \mu \mathrm{g}$ protein

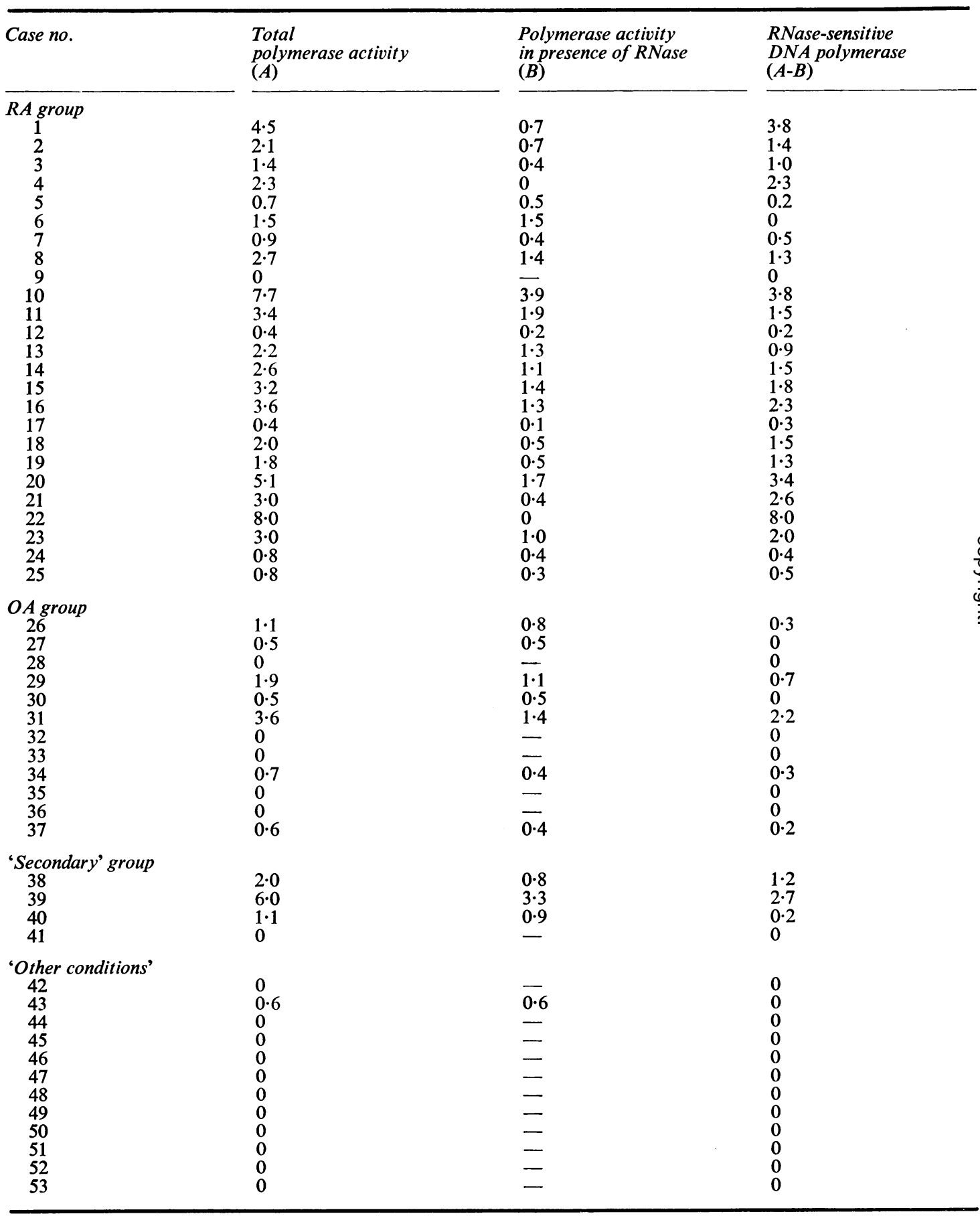


1972) or glycerol gradients (Gulati, Axel, and Spiegelman, 1972).

\section{Results}

The crude enzyme extracts prepared by high-speed centrifugation were assayed for the presence of endogenous RNase-sensitive DNA polymerase. Table II shows the result of the assays done, first without ribonuclease, then after preincubation with this enzyme. The activities of the membranes are expressed as an increase in acid-precipitable counts per minute over the first $30 \mathrm{~min}$ of the incubation per $\mathrm{mg}$ protein. Normally the mean value from two enzyme concentrations was recorded. With some membranes the incorporation of labelled nucleic acid precursors into acid-insoluble material was not a linear function of time after about $30 \mathrm{~min}$. Fig. 1 shows the assay of membrane of Case 16, an RA patient. Some membranes, particularly from the patients without arthritis, showed no increase in acid-precipitable counts over the normal incubation period. In these cases, $40 \mu \mathrm{l}$ samples of enzyme extract were used and the incubation continued over 2 hours, still with no demonstrable activity.

It may be seen from Table II that there is some poly-

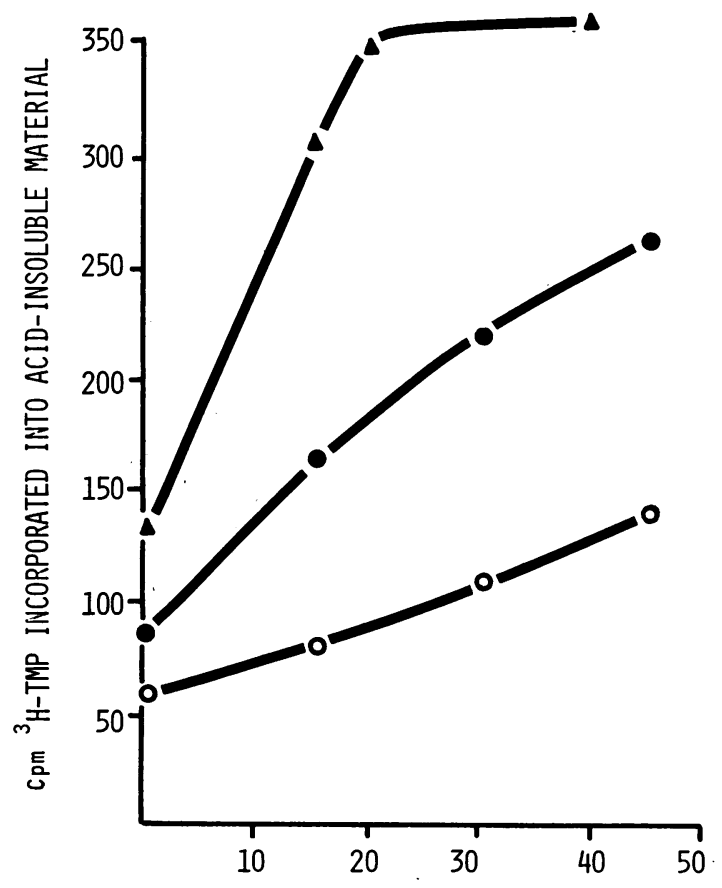

MINUTES

FIG 1 Endogenous DNA polymerase activity of $R A$ synovial membrane from Case 16. Assay conditions as in Methods, using $20 \mu l$ crude enzyme preparation $\bullet, 40 \mu l \Delta$, and $20 \mu$ lafter preincubation with RNase $\bigcirc$ merase activity not dependent on RNA as template. This is presumably due to the presence of some cellular DNA polymerases in the crude enzyme preparation. In the final column in Table II, the polymerase activity dependent on RNA is obtained by subtracting the activity after preincubation with RNase from that without RNase treatment. This is taken as being endogenous RNase-sensitive DNA polymerase activity.

The presence of this activity was of interest as a possible marker of oncorna virus, particularly as there was a clear-cut difference between the four groups. The mean activity for the RA group was 1.7, for osteoarthrosis 0.3 , for 'secondary' 1.0 , and for 'other conditions' 0 . However, there are obvious differences between RA synovial membrane on the one hand and the controls on the other. The former is characterized by massive proliferation of lining cells and extensive infiltration with cells of the lymphocyte series. As these cells have an RNA-primed DNA polymerase (Bobrow and others, 1972), it was necessary to determine whether the activity in the RA membranes (in particular) was of this type or was a true viral RNA-dependent DNA polymerase.

It is known that crude preparations of viral polymerases prefer hybrid synthetic template/primers such as poly-A.d(T) $)_{10}$ to double-stranded DNA synthetic templates such as poly-d(A-T), while this is not true of the cellular polymerases (Goodman and Spiegelman, 1971). The activity of some membranes was therefore determined in the presence of these two synthetic templates and, as shown in Table III, poly$\mathrm{d}(\mathrm{A}-\mathrm{T})$ at least doubled DNA synthesis, whereas poly-A.d(T) $)_{10}$ had no effect.

High concentrations of actinomycin D inhibit DNA-directed DNA synthesis but do not affect the first step of viral reverse transcriptase activity, which is the synthesis of an RNA-DNA hybrid (McDonnell, Quintrell, Garapin, Fanshier, Levinson, and Bishop,

Table III Effect of artificial templates on polymerase activity of synovial membranes, expressed as a ratio of endogenous activity to activity in the presence of poly$d(A-T)$ and poly- $A \cdot d(T)_{10}$

\begin{tabular}{|c|c|c|c|}
\hline Case no. & Endogenous & Poly-d $(A-T)$ & Poly-A.d(T) 10 \\
\hline $\begin{array}{c}R A \text { group } \\
12 \\
19 \\
20 \\
21 \\
22\end{array}$ & $\begin{array}{l}1 \\
1 \\
1 \\
1 \\
1\end{array}$ & $\begin{array}{l}4 \cdot 7 \\
4 \cdot 2 \\
1 \cdot 2 \\
3 \cdot 2 \\
2 \cdot 0\end{array}$ & $\begin{array}{l}1.2 \\
1.1 \\
0.7 \\
1 \\
1.2\end{array}$ \\
\hline $\mathrm{OA}_{37}$ group & 1 & $3 \cdot 5$ & $1 \cdot 2$ \\
\hline $\begin{array}{l}\text { Secondary } \\
\text { group } \\
39\end{array}$ & 1 & - & 0.8 \\
\hline
\end{tabular}




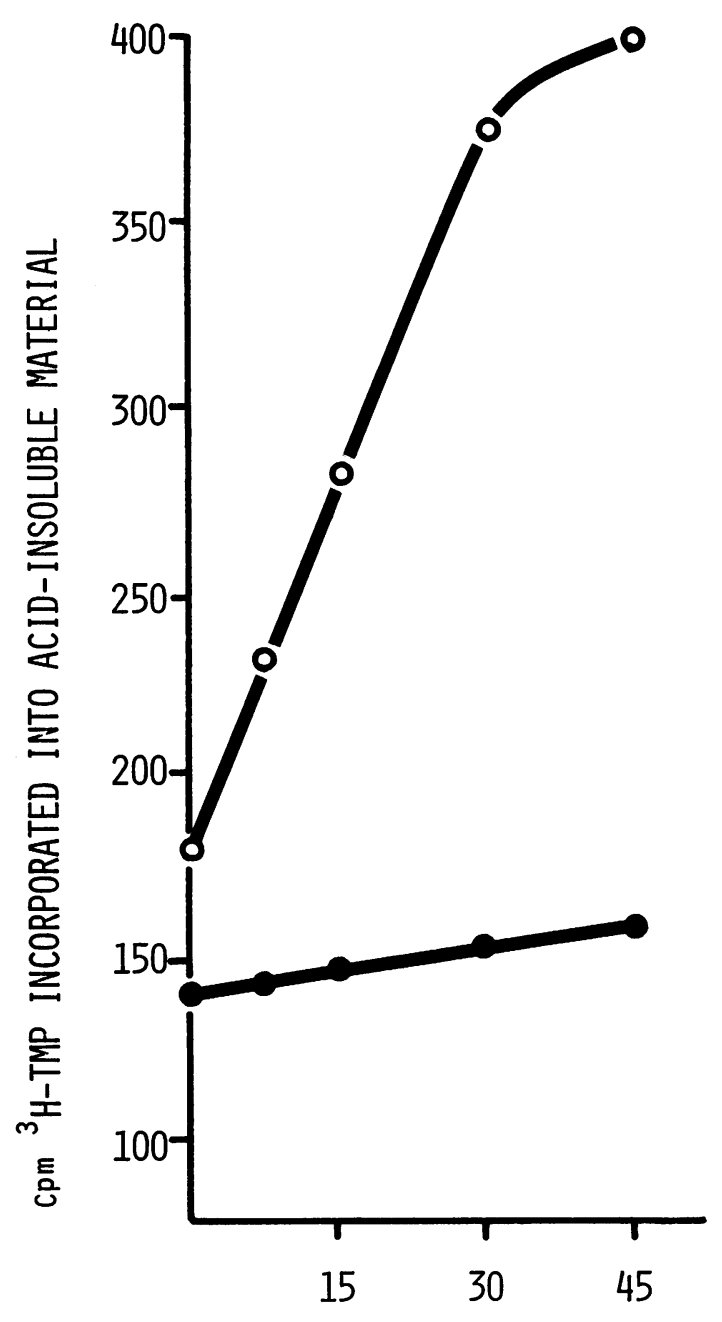

\section{MINUTES}

FIG. 2 Effect of actinomycin $D$ on endogenous DNA polymerase activity of synovial membrane of Case 39 from 'secondary' group. Actinomycin $D(50 \mu \mathrm{g} / \mathrm{ml}$ dissolved in polymerase buffer) was added to assay mixture or polymerase buffer alone 0

1970). Actinomycin D was therefore added to the assay mixture of several membranes and samples taken at 7, 15, 30, and $45 \mathrm{~min}$. Even at $7 \mathrm{~min}$ there was marked inhibition of incorporation into acid-insoluble product and this is illustrated for one membrane (Case 39) from the 'secondary' group in Fig. 2. Table IV shows the inhibition in the 11 membranes tested.

Finally, an attempt was made to analyse the endogenous product of the polymerase system of $\mathrm{Cs}_{2} \mathrm{SO}_{4}$ and glycerol gradients. It proved difficult to obtain a membrane preparation of sufficient size and activity to do this satisfactorily. However, with the few mem- branes tried there was never any suggestion of the formation of an intermediate RNA-DNA hybrid. This should band at a density of about $1.66 \mathrm{~g} / \mathrm{ml}$ on $\mathrm{Cs}_{2} \mathrm{SO}_{4}$ equilibrium density centrifugation (Sarngadharan and others, 1972) and have sedimentation coefficient of 70S on a glycerol gradient (Gulatiand others, 1972). All the radioactivity banded in the DNA region, that is with density around 1.41 on $\mathrm{Cs}_{2} \mathrm{SO}_{4}$ equilibrium density centrifugation and near the top of the glycerol gradient.

As the above results were not indicative of a viral RNA-dependent DNA polymerase, it was thought necessary to check the assay conditions using a known positive control. Use was made of a human glioma cell line transformed with Rous sarcoma virus, 118 MG-EH (Pontén and Macintyre, 1968) (kindly provided by Dr. Jan Pontén). A pellet was prepared from cell lysates as described for the synovial membrane cells. In this case there was stimulation of incorporation into acid insoluble material by at least fifteenfold in the presence of poly-d(A-T), and in addition polyA.d(T $)_{10}$ stimulated the activity by at least threefold. There was still incorporation of ${ }^{3} \mathrm{H}-\mathrm{TMP}$ into acidinsoluble product over the first part of the incubation period in the presence of actinomycin $D$, although it eventually caused about $40 \%$ inhibition of activitys As with the membrane preparations, it was difficule to obtain sufficient product to analyse it on $\mathrm{Cs}_{2} \mathrm{SO}_{6}-$ and glycerol gradients, though evidence suggeste that a labelled intermediate RNA-DNA hybrid was being formed.

\section{Discussion}

It may be seen from Table II that 23 out of the 25 synovial membrane preparations from patients with RA had endogenous DNA polymerase activity. Although the dependence of the activity on RNA as shown by the sensitivity of the reaction to preincubation with RNase was variable, in most specimens it was substantial and in marked contrast to membranes from osteoarthrotic patients or traumatized joints. Thus, none of the membranes from the nonarthritic group showed any endogenous RNase-sensitive DNA polymerase activity. Of the osteoarthrotic patients the results were more varied; seven had no activity and the remaining five had some. In the group of patients with secondary osteoarthritis, three out of the four showed activity. The residual activity, after RNase treatment, is presumably due to cellular DNAdependent DNA polymerases present in the crude enzyme preparations.

The difference between RA membranes and controls could be explained in various ways. One of the characteristic features of the former is the proliferation of the synovial membrane and it is obviously difficult to obtain adequate control material in terms of cellular composition for comparative observations. 
Table IV Effect of actinomycin D (Act D) on polymerase activity of synovial membranes, expressed as increase in cpm ${ }^{3} \mathrm{H}-\mathrm{TMP}$ incorporated into acid-insoluble material after 30-min incubation

\begin{tabular}{|c|c|c|c|}
\hline Case no. & $\begin{array}{l}\text { Polymerase } \\
\text { activity }\end{array}$ & $\begin{array}{l}\text { Polymerase } \\
\text { activity in } \\
\text { presence of Act } D\end{array}$ & $\% \frac{\text { Activity with Act D }}{\text { Activity without Act D }}$ \\
\hline \multicolumn{4}{|l|}{$R A$ group } \\
\hline 12 & 48 & 8 & $16 \cdot 7$ \\
\hline 19 & 290 & 25 & $8 \cdot 6$ \\
\hline 20 & 680 & 53 & $7 \cdot 5$ \\
\hline 21 & 200 & 15 & $7 \cdot 5$ \\
\hline 22 & 230 & 13 & $5 \cdot 7$ \\
\hline 25 & 35 & 0 & 0 \\
\hline \multicolumn{4}{|l|}{$O A$ group } \\
\hline 31 & 42 & 8 & $19 \cdot 0$ \\
\hline 34 & 40 & 4 & $10 \cdot 0$ \\
\hline 37 & 70 & 0 & 0 \\
\hline \multicolumn{4}{|c|}{ 'Secondary' group } \\
\hline 38 & 33 & 5 & $15 \cdot 0$ \\
\hline 39 & 195 & 12 & $6 \cdot 2$ \\
\hline
\end{tabular}

Membranes from patients in 3 other categories have been used: those with osteoarthrosis, those requiring arthrotomy following injury, and those from a small group with secondary osteoarthritis. These control membranes, particularly those from patients without arthritis, were quite different in morphology and in size from the rheumatoid membranes. It should be noted that, in addition to the variation in morphology of the synovial membranes in the different groups, they were not matched for age and sex; for instance, the RA patients tended to be female with average age of 58 years, whereas the nonarthritic patients tended to be male with average age of 32 .

Apart from proliferation of synovial lining cells, RA membranes are frequently infiltrated with large numbers of mononuclear cells of the lymphoid series, usually in excess of any inflammatory exudate found in degenerative or traumatic arthritis.

It is therefore necessary to consider whether the RNase-sensitive DNA polymerase activity found in RA synovial membranes is the product of an oncorna virus or if it is associated with the presence of a RNAprimed DNA polymerase of the type found in stimulated normal human lymphocytes (Bobrow and others, 1972). Several characteristics of the membrane enzyme suggest that, in fact, it is more likely to be from lymphocytes than virus. Thus, activity of the enzyme was not stimulated by poly-A.d(T) $)_{10}$, which is reported to increase DNA synthesis by viral reverse transcriptase, and actinomycin $D$ inhibited the enzyme. These findings are the reverse of those described for viral enzyme and in line with our own control experiments with extracts from a human glioma cell line (118 MG-EH) containing the Rous sarcoma virus genome. Finally, although it was difficult to obtain satisfactory quantities of the nucleic acid product of the polymerase reactions given the low levels of enzyme activity in the membranes (compared with those in the virions) ultracentrifugal analysis of phenol extracts of the synthesized material on glycerol and caesium sulphate gradients did not reveal a RNA-DNA hybrid, only DNA of small sedimentation constants.

We were unable, therefore, to find evidence of the presence of an oncorna virus in RA synovial membranes in terms of RNA-dependent DNA polymerase. This observation agrees with limited attempts by Grayzel (1973), who used cultured rheumatoid synovial cells and was unable to show incorporation of isotopically labelled uridine into particles of characteristic buoyant density on sucrose gradients; a marker for liberation of virus from cells.

It is not clear, however, from the literature whether failure to show reverse transcriptase is equable with the absence of an oncorna virus genome, or part of it, from a cell. The $118 \mathrm{MG}-\mathrm{EH}$ cell line and a hamster cell line, HT-1, transformed by murine sarcoma virus (Karpas, Cawley, Tuckerman, Flemans, and Hayhoe, 1971) both had viral reverse transcriptase. Although the former contains gs antigen, it is apparently free from virus particles (Macintyre, Grimes, and Vatter, 1969), and neither virions nor gs antigen have been shown in the latter (Karpas and others, 1971). On the other hand, Holder, Robey, and Vande Woude (1974) have shown with HBT-3 cells (supposedly a human breast tumour cell but with HeLa cell chromosomes) that reverse transcriptase activity is low except in cells treated with hormones and inducers; so perhaps the viral genes for the enzyme may not always be expressed and further experiments with rheumatoid synovial membranes and fibroblasts are necessary before final conclusions can be drawn.

This work was supported by a grant from the Nuffield Foundation. The HT-1 cells were kindly provided by Dr. A. Karpas. We wish to acknowledge the help of the consultant surgeons at the Princess Margaret Rose Hospital, Edinburgh, for providing synovial membrane specimens. We thank the staff of the Rheumatic Diseases Unit, Northern General Hospital, Edinburgh, for providing laboratory details of patients' sera. 


\section{References}

BALtimore, D. (1970) Nature (Lond.), 226, 1209 (RNA-dependent DNA polymerase in virions of RNA tumour viruses)

Bobrow, S. N., Smith, R. G., Reitz, M. S., and Gallo, R. C. (1972) Proc. Nat. Acad. Sci. U.S.A., 69, 3228 (Stimulated normal human lymphocytes contain a ribonuclease-sensitive DNA polymerase distinct from viral RNA-directed DNA polymerase)

Coffin, J. M., AND Temin, H. M. (1971) J. Virol., 7, 625 (Comparison of Rous sarcoma virus-specific deoxyribonucleic acid polymerases in virions of Rous sarcoma virus and in Rous sarcoma virus-infected chicken cells)

Goodman, N. C., and Spiegelman, S. (1971) Proc. Nat. Acad. Sci. U.S.A., 68, 2203 (Distinguishing reverse transcriptase of an RNA tumour virus from other known DNA polymerases)

GraYzel, A. I. (1973) Arthr. and Rheum., 16, 419 (Uridine incorporation into the media and RNA of cultured rheumatoid synovial cells)

Gulati, S. C., Axel, R., ANd Spiegelman, S. (1972) Proc. Nat. Acad. Sci. U.S.A., 69, 2020 (Detection of RNAinstructed DNA polymerase and high molecular weight RNA in malignant tissue)

Holder, W. D., Robey, W. G., and VANDe Woude, G. F. (1974) Nature (Lond.), 249, 759 (Activation of a C-type virus from the human carcinoma cell line HBT-3 by iododeoxyuridine and testosterone)

Karpas, A., Cawley, J., Tuckerman, E., Flemans, R., and Hayhoe, F. G. J. (1971) Brit. J. Cancer, 25, 779 (Cytochemistry, cytogenetics and ultrastructure of hamster tumour cells carrying mouse sarcoma viral genome (HT-1 cells))

Lowry, O. H., Rosebrough, N. J., Farr, A. L., ANd Randall, R. J. (1951) J. biol. Chem., 193, 265 (Protein measurement with the Folin phenol reagent)

McDonnell, J. P., Quintrell, N., Garapin, A. C., Fanshier, L., Levinson, W. E., ANd Bishop, J. M. (1970) Nature (Lond.), 228, 433 (DNA polymerases of Rous sarcoma virus: delineation of two reactions with actinomycin)

Macintyre, E. H., Grimes, R. A., And Vatter, A. E. (1969) J. Cell. Sci., 5, 583 (Cytology and growth characteristics of human tumour astrocytes transformed by Rous sarcoma virus)

MARMION, B. P. (1975) 'A microbiologist's view of infective hypotheses in rheumatoid arthritis', in 'Infection and Immunology in the Rheumatic Diseases', ed. D. C. Dumonde. Blackwell, London.

Neumark, T., Hollos, I., AND Farkas, K. (1973) Scand. J. Rheumatol., 2, 21 (Virus-like particles in rheumatoid synovium)

Palmer, D. G., AND Myers, D. B. (1973) Excerpta Med., International Congress Series, XIII Int. Cong. Rheumatol. 299, 27 (A search for viral imprints)

Pontén, J., AND Macintyre, E. H. (1968) Acta Path. Microbiol. Scand., 74, 465 (Long term culture of normal and neoplastic human glia)

Sarngadharan, M. G., Sarin, P. S., Reitz, M. S., and Gallo, R. C. (1972) Nature (New Biol.), 240, 67 (Reverse transcriptase activity of human acute leukaemic cells: purification of the enzyme, response to AMV 70S RNA, and characterization of the DNA product)

Schumacher, H. R. (1973) Excerpta Med., International Congress Series, XIII Int. Cong. Rheumatol., 299, 27 (Needle synovial biopsy: evidence for infectious agents including viruses as possible etiologies in arthritis)

Spiegelman, S., Kufe, D., Hehlmann, R., and Peters, W. P. (1973) Cancer Res., 33, 1515 (Evidence for RNA tumour viruses in human lymphomas including Burkitt's disease)

Spruance, S. L., Richards, O. C., Ward, J. R., AND Smith, C. B. (1974) Clin. Res., 22, 124A (Studies of reverse transcriptase activity in cultured rheumatoid synovial cells)

Temin, H. M., ANd Mizutani, S. (1970) Nature (Lond.), 226, 1211 (RNA-dependent DNA polymerase in virions of Rous sarcoma virus) 